\title{
Applicability and Efficacy Evaluation of Wudalianchi Mineral Mud Formula
}

Shiyu Wei, Yijie Du, Teng Fei, Li Li, Hong Meng, Yinmao Dong*

China Cosmetic Collaborative Innovation Center, Beijing Technology and Business University, Beijing, China

*Corresponding author: Yinmao Dong, China Cosmetic Collaborative Innovation Center, Beijing Technology and Business University, No. 11/33, Fucheng Road, Haidian District, Beijing, China Tel.: +861068984937 Fax: +861068984937 Email: ymdong2008@163.com

Received January 19, 2017

Revised February 15, 2017

Accepted February 17, 2017

Published March 30, 2017

\begin{abstract}
Purpose: This study was conducted to evaluate the stability, safety, and efficacy of Wudalianchi mineral mud formula. Methods: The stability of Wudalianchi mineral mud formula was studied by observing the state variations of mineral mud formula under cold, hot, thermal cycling, and illumination, respectively. And the safety of mineral mud was studied through human patch test. The skin moisture contents, water loss amount and lipid contents, and the skin gloss index were measured to study efficacy evaluation of mineral mud in human body. Results: The mineral mud of Wudalianchi is safe and stable. And the mineral mud could improve skin moisture and gloss. Conclusion: As a kind of raw material, Wudalianchi mineral mud has the unique function and good market potential.
\end{abstract}

Keywords: Cosmetics, Wudalianchi, Mineral mud, Formula, Efficacy evaluation

\section{Introduction}

海湾、湖泊等处的有机物和矿物质沉积后, 经过一系列复 杂的生物化学和物理化学变化 (Carretero, 2002) 形成矿物 泥，矿物泥中含有丰富的矿物泥、胶体成分、氨基酸等, 具有独特的美容、保健、治疗功效（Luo et al., 2009; Miko et al., 2008）。通过我国不同地区矿物泥调研（Du et al., 2016）发现其中五大连池矿物泥的临床应用最为突出。五 大连池矿物泥形成于著名的五大连池火山低温冷矿泉区, 是世界罕见的天然优质冷泉矿泥，素有神泥之称，资源储 量值为 $18.421 \times 104$ t（You et al., 2015; Liu, 2014）。其富 含多种微量元素及14酸、16酸等25种有机酸 (Wang et al., 2014）。研究表明, 五大连池矿泉及矿物泥中所含有的钠、

钾、钙、镁 (Wang \& Xie, 2007) 四种阳离子比例适当且和 人体体液各种离子比例相近（Guo, 2008），且矿物泥中尚 含有锌、锰、铜、钴等微量元素（Lu et al., 2000）。其中, 铁离子能够增强皮肤弹性与光泽度（Li \& Guo, 2001）;
铜离子则可以清除体内自由基，促进皮肤弹性蛋白合成（Hu， 1999）；镁离子在舒缓疲劳和抗应激方面具有一定的功效 (Huang, 2012)。

其作为新型矿产资源在医疗保健品的开发利用方面被科研 院所及广大消费者所重视。同时由于其中丰富的物质组 成, 是一般面膜基料所不具备的, 故此五大连池矿物泥的 美容功效也备受关注。

本研究对五大连池矿物泥面膜配方的稳定性、安全性、 人体功效性进行评价, 明确五大连池矿物泥功效作用点, 为五大连池矿物泥在化妆品领域的应用提供理论依据, 具 有一定实际应用价值。

\section{Methods}

\section{Reagents and instruments}

电热恒温水浴锅 $\left(45 \mathrm{~cm} \times 25 \mathrm{~cm}, 37^{\circ} \mathrm{C}\right.$; Beijing Changfeng 
Instrument, China）；数字显示搅拌器（EURO-ST 60 CS25; IKA, China) ; 电陶炉 (LC-E109S; Guangdong Shunde Zhongchen Electrical Appliance, China) ; 数字显示均质机

(T 25; IKA, Germany) ; 电子天平 (ML4002; Mettler Toledo, Swiss）。皮肤水分流失测试仪及测试探头（TM300; Courage+Khazaka Electronic, Germany）; 皮肤水分含量测试 仪及测试探头（CM825; Courage+Khazaka Electronic）；皮 肤油脂含量测试仪及油脂测试盒（SM815; Courage+Khazaka Electronic）；皮肤光亮度测试仪（GonioLux 4D; Orion TechnoLab, France) ; 斑试器（circular, diameter of $12 \mathrm{~mm}$; Beijing Baiyi Yida science and technology development, China) 。

混醇 (mixed alcohol; Nanjing Changjiang Jiangyu Petrochemical, China）; 辛酸/癸酸甘油三酯（caprylic/capric triglyceride, GTCC; Croda Chemicals Trading, China) ; 凡士 林（vaseline; Wuhan Hezhong Biochemical Manufacturing, China); 硬脂醇聚醚-2 (stearyl alcohol polyether-2, Brij S2; Changsha Zhongren Biotechnology, China) ; 硬脂醇聚醚-21 (stearyl alcohol polyether-21, Brij S21; Changsha Zhongren Biotechnology); 白油 (white oil; Freda bloomage Biotechnology, China）; 透明汉生胶 (xanthan gum; Changsha Zhongren Biotechnology) ; 高岭 土 (kaolin; Xilong Chemical, China) ; 五大连池火山矿物泥 (Wudalianchi volcanic mineral mud; Heilongjiang Wudalianchi
Municipal People's Government, China）；丙烯酰二甲基牛 磺酸铵/NP共聚物（acryloyl dimethyl ammonium taurine/NP Copolymer, AVC; Clariant Chemical, China) ；1，3-丁二醇

(1,3-butanediol; Changsha Zhongren Biotechnology)；苯 氧乙醇/乙基己基甘油（phenoxy ethanol/ethylhexyl glycerin, PE9010; Thor Specialty Chemical (Zhenjiang), China) ; 丙二醇/甲基异噻唑啉酮/碘丙炔醇丁基氨甲酸酯/氯化钠

(propylene glycol/methylisothiazolinone/iodopropynyl butylcarbamate/sodium chloride, MTI; Thor Specialty Chemical (Zhenjiang)) ; 去离子水 (deionized water; laboratory preparation) 。

\section{Experimental methods}

1) Wudalianchi mineral mud formula preparation 五大连池矿物泥配方、基质配方（具体配方见Table 1），实 验室自制。

具体配置步骤为: 将 $\mathrm{A}$ 相各原料混合均匀, 加热到 $80^{\circ} \mathrm{C}$; 将 $\mathrm{B}$ 相原料混合均匀, 加热到 $80^{\circ} \mathrm{C}$ 。将 $\mathrm{B}$ 相缓慢倒入 $\mathrm{A}$ 相中, 7000 $\mathrm{r} / \mathrm{min}$ 均质 $5 \mathrm{~min}$ 。均质完成后, 搅拌降温至 $40^{\circ} \mathrm{C}$ 以下, 依次加 入C相, 搅拌均匀, 出料灌装, 得到五大连池矿物泥面膜。

2) Stability observation

观测五大连池矿物泥面膜配方在离心、冷藏、热、冷热交 替、光照条件下的稳定性, 观测 30 days并记录配方外观、

Table 1. Recipe for Wudalianchi mineral mud mask and matrix formulation

\begin{tabular}{|c|c|c|c|c|}
\hline \multirow{2}{*}{ Group } & \multirow{2}{*}{ Order number } & \multirow{2}{*}{ Material name } & \multicolumn{2}{|c|}{ Weight (\%) } \\
\hline & & & Wudalianchi mineral mud & Matrix formulation \\
\hline \multirow{6}{*}{ A } & 1 & Mixed alcohol & 2.00 & 2.00 \\
\hline & 2 & GTCC & 5.00 & 5.00 \\
\hline & 3 & White oil & 3.00 & 3.00 \\
\hline & 4 & Vaseline & 2.00 & 2.00 \\
\hline & 5 & Brij S21 & 2.00 & 2.00 \\
\hline & 6 & Brij S2 & 2.00 & 2.00 \\
\hline \multirow{6}{*}{ B } & 7 & Wudalianchi mineral mud & 10.00 & 0.00 \\
\hline & 8 & Kaolin & 0.00 & 10.00 \\
\hline & 9 & Xanthan gum & 0.15 & 0.15 \\
\hline & 10 & AVC & 0.30 & 0.30 \\
\hline & 11 & 1,3-Butanediol & 4.00 & 4.00 \\
\hline & 12 & Deionized water & To 100.00 & To 100.00 \\
\hline \multirow{2}{*}{ C } & 13 & PE9010 & 0.60 & 0.60 \\
\hline & 14 & MTI & 0.08 & 0.08 \\
\hline
\end{tabular}

GTCC, caprylic/capric triglyceride; Brij S21, stearyl alcohol polyether-21; Brij S2, stearyl alcohol polyether-2; AVC, acryloyl dimethyl ammonium taurine/VP copolymer; PE9010, phenoxy ethanol/ethylhexyl glycerin; MTI, propylene glycol/methylisothiazolinone/iodopropynyl butylcarbamate/ sodium chloride. 


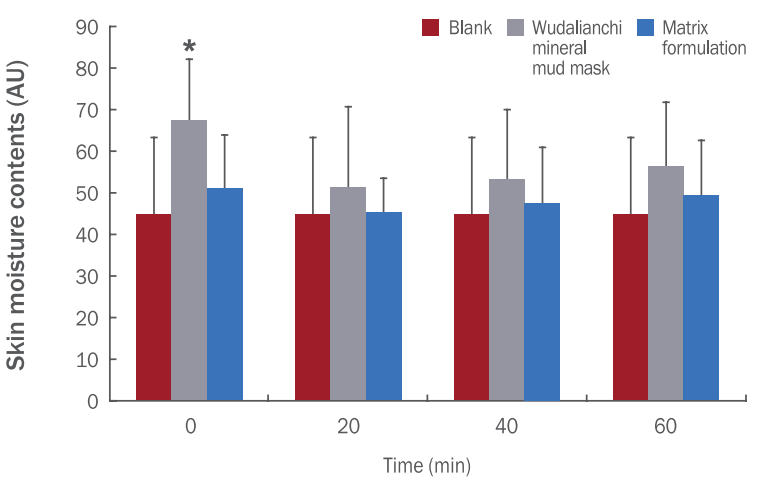

Figure 1. Change of moisture contents of Wudalianchi mineral mud mask and matrix formulation.

After using Wudalianchi mineral mud mask, skin moisture contents was significantly different from that of the blank group and the matrix formulation group at $0 \mathrm{~min}$, which indicated that Wudalianch mineral mud had better moisture retentions. When using Wudalianchi mineral mud mask, skin moisture contents was still higher than other two groups at 20,40, and 60 min. ${ }^{*} p<0.05$ compared with the blank group.

气味等变化情况。离心条件为: 转速 $3000 \mathrm{r} / \mathrm{min}$, 时间30 $\min$ ，观测其配方是否有破乳、分层等现象。冷藏环境为 把样品放入 $4 \pm 1^{\circ} \mathrm{C}$ 冰箱中; 热环境为把样品放入 $45 \pm 1^{\circ} \mathrm{C}$ 不 透光烘箱中; 冷热交替环境为把样品瓶放入 $-15^{\circ} \mathrm{C}-45 \pm 1^{\circ} \mathrm{C}$ 隔天轮换的高低温交变箱中; 光照条件为把样品放入 $28 \pm 1^{\circ} \mathrm{C}$ 光照培养箱。

3) Safety and efficacy evaluation

(1) Screening of subjects

选取受试者30人, 要求20-45岁女性, 且皮肤无明显破损; 复合赫尔辛基宣言; 受试者排除条件符合《化妆品接触性皮 炎诊断标准及处理原则》的纳入、排除标准; 无严重系统性 疾病、无免疫缺陷或自身免疫疾病; 无活动性过敏性疾病; 对护肤类化妆品无过敏史；1个月内未曾全身使用激素类药 物及免疫抑制剂, 非妊娠或哺乳期; 无伦理学禁忌。

(2) Test indicators

皮肤水分含量：水分含量变化反映在测试周期内，实验区 域水分含量随时间变化规律。其值越大, 水分含量越大, 反 之，水分含量越小。

水分经皮散失（Gardien et al., 2016）：水分散失变化反映 在测试周期内, 实验区域水分散失随时间变化规律。其值越 小，水分散失越少，锁水能力越强; 反之，锁水能力越弱。 光泽度（Jiao et al., 2015）：光泽度数值反映在测试周期 内, 实验区域皮肤光泽度情况。其值越大, 皮肤越光泽, 反之, 皮肤越不光泽。

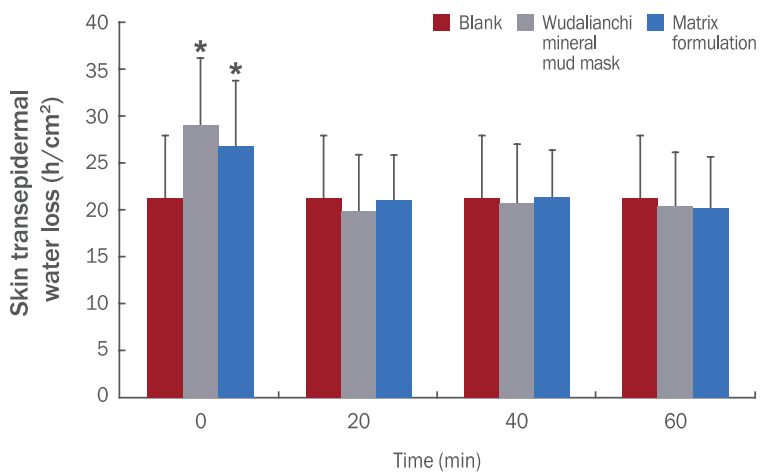

Figure 2. Change of transepidermal water loss of Wudalianchi mineral mud mask and matrix formulation.

Values of skin water loss in Wudalianchi mineral mud mask group and matrix formation group were significantly higher than that of the blank group at 0 min. But after a certain period of time, the values of them were decreased as same as that of the blank group. Because skin just after washing the mask may have a higher water loss than the blank group, but after a period time the water loss decreased due to stability of skin. ${ }^{*} p<0.05$ compared with the blank group.

油脂含量（Potcoava et al., 2014）：油脂含量反映在测试 周期内, 实验区域面部油脂分泌情况。其值越大, 油脂含 量越大, 反之, 油脂含量越小。

4) Patch experiment

选择30例受试者, 取待测五大连池矿物泥面膜配方 0.02 g放入斑试器内, 对照孔为空白对照。将样品和空白对照 均贴于受试者的前臂曲侧, 用手掌轻压使之均匀地贴敷于 皮肤上, 持续 $24 \mathrm{~h}$, 去除斑试器后间隔 $30 \mathrm{~min} 、 24 \mathrm{~h} 、 48 \mathrm{~h}$ 观察皮肤反应, 并记录观察结果。

5) Efficacy evaluation experiment

测试环境要求恒温恒湿, 测试温度为 $22 \pm 1^{\circ} \mathrm{C}$, 湿度为 $50 \pm 5 \%$, 测试前样品需在符合标准的房间内放置至少 $30 \mathrm{~min}$ 。

选择受试者左、右脸颊为受试区, 进行随机标记, 测 试前受试者用清水清洗测试部位后, 在此环境下静坐 20 $\mathrm{min}$, 测试皮肤水分含量、水分散失量、油脂含量、光泽 度。皮肤本底值测试完毕, 使用乳胶指套将配置好的配 方与 $0.5 \mathrm{~g} / \mathrm{cm}^{2}$ 的样品用量均匀涂抹于实验区域内, 使用 15 min，使用后 $0 \mathrm{~min}, 20 \mathrm{~min}, 40 \mathrm{~min}, 60 \mathrm{~min}$ 测试皮肤水分 含量、水分散失量, 使用后 $0 \mathrm{~min}$ 测试皮肤光泽度, 使用后 150 min测试油脂含量。在测试期间，不涂抹任何化妆品。

6) Data analysis

采用SPSS 20.0 统计软件进行数据分析。统计分析前对各 


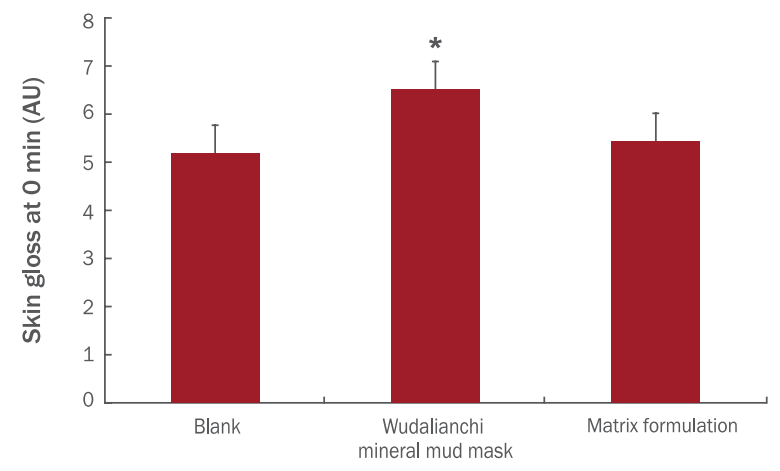

Figure 3. Change of skin gloss of Wudalianchi mineral mud mask and matrix formulation at $\mathbf{0} \mathbf{~ m i n}$.

After using the Wudalianchi mineral mud mask, the skin gloss was significantly higher than that of the blank group and the matrix formulation group, indicating that the Wudalianchi mineral mud mask could improve the skin gloss. ${ }^{*} p<0.05$ compared with the blank group.

参数进行正态分布和方差齐性检验。采用 $\mathrm{t}$ 检验, 显著性 水平为 $95 \%$ 的置信区间 $(p<0.05)$ 。

\section{Results and Discussion}

\section{Stability of Wudalianchi mineral mud mask}

五大连池矿物泥面膜在光照 $28 \pm 1^{\circ} \mathrm{C}$ 、热 $45 \pm 1^{\circ} \mathrm{C}$ 、冷冻 $-15 \pm 1^{\circ} \mathrm{C}$ 、冷热交替- $15-45 \pm 1^{\circ} \mathrm{C}$ 隔天调换四个环境下进 行为期30天的稳定性测试期间无破乳、分层、析出现象, 味道为产品配方特征气味; 通过离心实验, 未见产品发生 分层、分离现象, 结果见Table 2。表明五大连池矿物泥 面膜有较好的稳定性。

\section{Safety test of Wudalianchi mineral mud mask}

五大连池矿物泥配方安全性检测试验结果及皮肤不良反 应分级见Table 3和 Table 4。参考2015版《化妆品安全技 术规范》的要求 (State Food and Drug Administration, 2015），判定五大连池矿物泥配方对人体无不良反应。

\section{Efficacy evaluation of Wudalianchi mineral mud mask}

1) Skin moisture contents

由Figure 1得, 五大连池矿物泥面膜后的 $1 \mathrm{~h}$ 内, 受试部位 与空白区和与基质配方区比较, 0 min 时样品区皮肤的水 分含量发生了显著性提高, 在 $20 \mathrm{~min}$ 后的皮肤含水量呈上 升趋势, 并且均大于肌肤本底值, 说明五大连池矿物泥面 膜具有较好的保湿性, 能够在一段时间内保持肌肤水分。

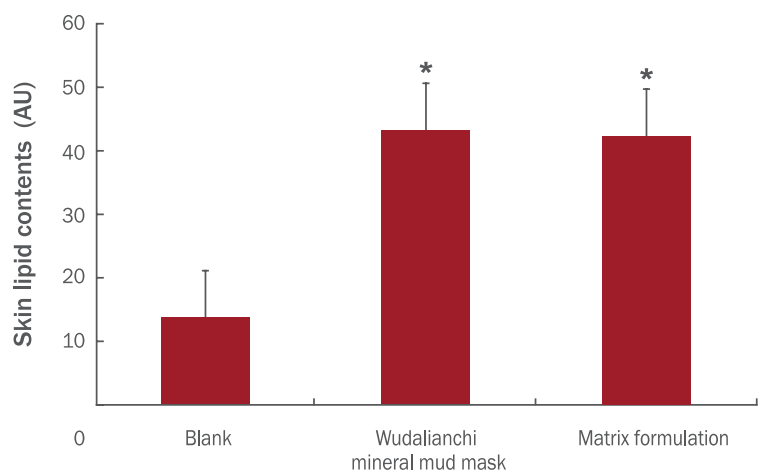

Figure 4. Change of lipid contents of Wudalianchi mineral mud mask and matrix formulation at $\mathbf{1 5 0} \mathbf{~ m i n}$.

Compared with the blank group, Wudalianchi mineral mud mask and the matrix formulation could increase the contents of skin lipid after using for $150 \mathrm{~min}$, both of them have significant difference. ${ }^{*} p<0.05$ compared with the blank group.

\section{2) Skin transepidermal water loss}

由Figure 2得, 在使用五大连池矿物泥面膜后的 $1 \mathrm{~h}$ 内, 受试部位与空白区比较, 皮肤水分散量在 $0 \mathrm{~min}$ 时增加, 基质配方与空白区比较同样增加, 可能是因为样品使用结 束后需要用水洗去, 导致皮肤在刚刚清洁后皮肤水散量显著 增高，在20 min、40 min、60 min时，即皮肤稳定一段时间 后皮肤水散量较之前降低。

\section{3) Skin gloss}

由Figure 3得, 在使用五大连池矿物泥面膜后测量皮肤光 泽度数值, 受试部位与空白区和基质配方区比较, 皮肤光 泽度数值在 $0 \mathrm{~min}$ 时显著增加, 说明在使用五大连池矿物 泥面膜后可提高皮肤光泽度, 且效果明显优于基质配方。

\section{4) Skin lipid contents}

如Figure 4得, 在使用五大连池矿物泥面膜后的 $150 \mathrm{~min}$ 后, 受试部位与空白区和基质配方区比较, 皮肤油脂含量 有显著的增高。由此可见五大连池矿物泥面膜可促进油脂 分泌, 润泽保护肌肤。

\section{Conclusion}

通过对五大连池矿物泥面膜稳定性、安全性、人体功效 性研究表明五大连池矿物泥面膜安全、稳定, 且能够在短 时间内提高皮肤水分含量, 降低皮肤水分散失率, 提高皮 肤光泽度。

五大连池矿物泥提高皮肤含水量可能由于五大连池矿物 
泥中功效成分都是以离子态存在有关, 通过各种元素的作 用，会产生强大的渗透压，使细胞内外离子达到平衡，丰 富的矿物质具有双向调节肌肤水分作用，从而改善皮肤 含水量（Du \& Huo, 2006）。五大连池能够在短时间内提 高皮肤光泽度可能由于五大连池矿物泥摩擦系数较大，在 洗涤过程中去除部分皮肤老化角质，而矿物泥粒径大小与 摩擦性能对皮肤光泽度的影响还需要进一步的研究（Zhai et al., 2012）。五大连池矿物泥面膜及基质配方在使用 后120 min能够显著提高皮肤油脂分泌，但末见显著性差 异，可能与配方中添加了 $8 \%$ 的油脂成分有关。

此次对五大连池矿物泥面膜稳定性、安全性、功效性进 行了系统研究, 对五大连池矿物泥这种新型矿泥资源在化 妆品领域的应用具有一定的指导意义。其实五大连池矿泉 矿泥的民间疗法有很多, 例如: 矿泉饮疗、矿泉矿泥浴
疗、矿泉吸入和矿泉矿泥灌洗法等, 各种疗法对不同疾病 的治疗有效率各有不同，总有效率在 $85-95 \%$ 以上（Guo et al., 1998）。其中对于脱发、关节炎等疾病有独特的 临床效果。研究结果显示其中治疗脱发有效率为 $97.7 \%$ （Yang \& Xie, 1998），治疗类风湿性关节炎的总有效率 达到95\%以上（Zhang et al., 1998）。这些五大连池矿物 泥的独特疗效以及做为化妆品功效原料的独特功效点还有 待进一步挖掘。

\section{Table 2. Stability of Wudalianchi mineral mud mask}

\begin{tabular}{lcccc}
\hline Condition & 7 days & 14 days & 28 days & 50 days \\
Normal conditions & $\sqrt{ }$ & $\sqrt{ }$ & $\sqrt{ }$ & $\sqrt{ }$ \\
Illumination & $\sqrt{ }$ & $\sqrt{ }$ & $\sqrt{ }$ & $\sqrt{ }$ \\
Cold & $\sqrt{ }$ & $\sqrt{ }$ & $\sqrt{ }$ & $\sqrt{ }$ \\
Hot & $\sqrt{ }$ & $\sqrt{ }$ & $\sqrt{ }$ \\
\hline Thermal cycling & $\sqrt{ }$ & & $\sqrt{ }$ \\
\hline
\end{tabular}

Note: $\sqrt{ }$ indicate stable.

Table 3. Results of removal of Wudalianchi mineral mud mask after $0.5 \mathrm{~h}, 24 \mathrm{~h}$, and $48 \mathrm{~h}$

\begin{tabular}{|c|c|c|c|c|c|c|}
\hline \multirow{2}{*}{ Division } & \multicolumn{2}{|c|}{$0.5 \mathrm{~h}$} & \multicolumn{2}{|c|}{$24 \mathrm{~h}$} & \multicolumn{2}{|c|}{$48 \mathrm{~h}$} \\
\hline & Blank & Mask $^{1)}$ & Blank & Mask & Blank & Mask \\
\hline Negative reaction $(0)$ & $30^{2)}$ & 28 & 30 & 30 & 30 & 30 \\
\hline Mild erythema, dry, wrinkle (1) & 0 & 2 & 0 & 0 & 0 & 0 \\
\hline Edema, erythema, papules, wheal, desquamation fracture (2) & 0 & 0 & 0 & 0 & 0 & 0 \\
\hline Obvious erythema, edema, blisters ( 3 ) & 0 & 0 & 0 & 0 & 0 & 0 \\
\hline $\begin{array}{l}\text { Severe erythema, edema, erosion, blister, } \\
\text { pigmentation or depigmentation, change like acne (4) }\end{array}$ & 0 & 0 & 0 & 0 & 0 & 0 \\
\hline
\end{tabular}

${ }^{1)}$ Wudalianchi mineral mud mask.

${ }^{2)}$ Number of subjects.

Table 4. Grade of cutaneous reaction

\begin{tabular}{ccl}
\hline Reaction degree & Grade & Cutaneous reaction \\
- & 0 & Negative reaction \\
\pm & 1 & A suspicious reaction; only a faint erythema \\
+ & 2 & Weak positive reaction (erythema reaction): erythema, infiltration, edema, and papules \\
++ & 3 & $\begin{array}{l}\text { Strong positive reaction (erythema reaction): erythema, infiltration and edema can have papules; } \\
\text { Reaction can exceed the test area. }\end{array}$ \\
& 4 & $\begin{array}{l}\text { Strong positive reaction (erythema reaction): obvious erythema, severe infiltration, edema, and } \\
\text { fusion of herpes; Reaction can exceed the test area. }\end{array}$ \\
\hline
\end{tabular}




\section{References}

Carretero MI. Clay minerals and their beneficial effects upon human health. a review. Applied Clay Science, 21: 155163, 2002.

Du SY, Huo WH. Anti-wrinkle and skin-moisturizing effects of minerals and algae in brine water from Shanxi Yuncheng salt lake. Detergent \& Cosmetics, 29: 18-21, 2006.

Du Y, Deng X, Li L, Dong Y. The investigation of function of mineral mud for the skin. Asian Journal of Beauty and Cosmetology, 14: 98-104, 2016.

Gardien KL, Baas DC, de Vet HC, Middelkoop E. Transepidermal water loss measured with the Tewameter TM300 in burn scars. Burns, 42: 1455-1462, 2016.

Guo XM. Study on the effect of trace elements of the volcano mud in Wudalianchi on the skin. Studies of Trace Elements and Health, 25: 61-62, 2008.

Guo XS, Ma B, Fu C. Observation of the effects of mineral spring bath on some normal physilogical functions of human body. Chinese Journal of Convalescent Medicine, 7: 5-7, 1998.

Hu WY. Trace elements in cosmetics. Guangdong Trace Elements Science, 6: 13-15, 1999.

Huang R. Application of minerals in cosmetics. Detergent \& Cosmetics, 35: 43-46, 2012.

Jiao ZX, Wang Y, Wang XY, Dong YM, Meng $\mathrm{H}$, Zhao H. Research on gloss evaluation of facial skin based on Retinex algorithm. China Surfactant Detergent \& Cosmetics, 45: 443-446, 2015.

Li FH, Guo JY. Protection and utilization of Wudalianchi mud. Heihe Journal, 5: 44-45, 2001.

Liu JJ. Wudalianchi's natural cold mineral resources are rare in the world: an interview with Jianbo Yang, mayor of Wudalianchi. China Food, 16: 22-23, 2014.

Lu YQ, Bai J, Ni XH, Lu Z, Sun XY, Liu Z. Wudalianchi slime antiinflammatory and promote hair growth effect. Chinese Traditional and Herbal Drugs, 31: 281-283, 2000.
Luo HY, Wu HH, Xie YH, Sang WG, Zhang J. Study on the antioxidant properties and whitening efficacy of Zhejiang xiushan sea mud water soluble system. Ocean Development and Management, 26: 52-56, 2009.

Miko S, Koch G, Mesić S, Šparica-Miko M, Šparica M, Čepelak R, Bačani A, Vreča P, Dolenec T, Bergant S. Anthropogenic influence on trace element geochemistry of healing mud (peloid) from Makirina Cove (Croatia). Environmental Geology, 55: 517-537, 2008.

Potcoava MC, Futia GL, Aughenbaugh J, Schlaepfer IR, Gibson EA. Raman and coherent anti-Stokes Raman scattering microscopy studies of changes in lipid content and composition in hormone-treated breast and prostate cancer cells. Journal of Biomedical Optics, 19: 111605, 2014.

State Food and Drug Administration. Safety and technical standards for cosmetics. State Food and Drug Administration, Beijing, pp541-542, 2015.

Wang XY, Xie ZH, Fang ZX. Application of Wudalianchi volcanic mineral mud in cosmetics. Detergent \& Cosmetics, 37 : 26-29, 2014.

Wang XY, Xie ZH. Determination of trace elements in the mud in Wudalianchi. Studies of Trace Elements and Health, 24: 69, 2007.

Yang YM, Xie ZH. Study on the mechanism of Wudalianchi mineral spring mineral water treating alopecia. Chinese Journal of Convalescent Medicine, 7: 10, 1998.

You CY, Ye XY, Zhang HY, Cao YQ. Distribution characteristic and reserve evaluation of the peloid in the Wudalianchi area, Heilongjiang province. Geology and Exploration, 51: 61-67, 2015.

Zhai ZH, Li W, Pang Q. Effects of scrub facial cleanser on the friction properties of human skin. Tribology, 32: 606611, 2012.

Zhang Y, Chang X, He T. Observattion on treatment of 80 cases of rheumatoid arthritis by natural mineral water of Ww Da Lian Chi. Chinese Journal of Convalescent Medicine, 7: 4-5, 1998. 


\section{中文摘要}

\section{五大连池矿物泥配方适用性及人体功效研究}

韦诗雨，杜一杰，费腾，李丽，孟宏，董银卯”

北京工商大学中国化妆品协同创新中心，北京，中国

目的：对五大连池矿物泥配方进行稳定性、安全性、人体功效性评价。方法：通过观测配方在冷、热、冷热交替、光照条 件下的状态变化，研究其稳定性；通过人体斑贴实验研究其安全性；通过皮肤含水量、水分散失量、油脂含量、皮肤光 泽度指标研究其人体功效。结果：五大连池矿物泥安全、稳定且具有一定保湿、提高皮肤滋润度、提高皮肤光泽度功效。 结论: 五大连池矿物泥做为化妆品功效原料具有独特功效特点，有很好的市场应用潜力。

关键词: 化妆品，五大连池，矿物泥，配方，人体功效 


\section{국문초록}

\section{Wudalianchi 미네랄머드 제형의 응용가능성 및 인체효능평가}

위시우, 두일걸, 비등, 리려, 맹홍, 동은묘*

북경공상대학 중국화장품공동혁신센터, 북경, 중국

목적: 본 연구는 Wudalianchi 미네랄머드 제형의 안정성, 안전성 및 효능을 평가하여 향후 화장품 원료로서의 응용가능성을 확인하 고자 진행되었다. 방법: Wudalianchi 미네랄머드 제형의 안정성은 저온, 고온, 저온/고온 순환, 광선 등의 조건에서 상태 변화를 관 찰하여 확인하였고, Wudalianchi 미네랄머드 제형의 안전성은 첩포시험을 통해 확인하였다. 그리고 Wudalianchi 미네랄머드 제형 의 유효성평가는 피부 수분 함량, 수분 손실량, 유지 함량 및 피부 광택 지수를 측정하여 확인하였다. 결과: Wudalianchi 미네랄머드 제형은 안정하고 안전할 뿐만 아니라. 피부의 수분과 윤기를 향상시킬 수 있는 효능을 갖고 있다. 결론: Wudalianchi 미네랄머드는 화장품 원료로서 충분히 활용 가능한 독특한 효능을 갖고 있으므로, 화장품 시장에서의 응용 가능성이 우수할 것으로 사료된다.

핵심어: 화장품, Wudalianchi, 미네랄머드, 제형, 인체효능

\section{참고문헌}

두일걸, 등소봉, 리려, 동은묘. 미네랄머드의 피부작용에 대한 연구. 아시안뷰티화장품학술지, 14: 98-104, 2016. 